\title{
Taxonomic investigation of representatives of the genus Sphaerotilus: descriptions of Sphaerotilus montanus sp. nov., Sphaerotilus hippei sp. nov., Sphaerotilus natans subsp. natans subsp. nov. and Sphaerotilus natans subsp. sulfidivorans subsp. nov., and an emended description of the genus Sphaerotilus
}

Correspondence Margarita Grabovich margarita grabov@mail.ru
Elena Gridneva, ${ }^{1}$ Elena Chernousova, ${ }^{1,2}$ Galina Dubinina, ${ }^{3}$ Vladimir Akimov, ${ }^{2}$ Jan Kuever, ${ }^{4}$ Ekaterina Detkova ${ }^{3}$ and Margarita Grabovich ${ }^{1}$

\footnotetext{
${ }^{1}$ Department of Biology, University of Voronezh, Universitetskaya pl. 1, 394006 Voronezh, Russia ${ }^{2}$ G. K. Skryabin Institute of Biochemistry and Physiology of Microorganisms, Russian Academy of Sciences, Prospect Nauki 5, 142290 Pushchino, Russia

${ }^{3}$ S. N. Winogradsky Institute of Microbiology, Russian Academy of Sciences, Prospect 60-letiya Oktyabrya 7/2, 117312 Moscow, Russia

${ }^{4}$ Department of Microbiology, Bremen Institute for Materials Testing, Paul-Feller Str. 1, D-28199 Bremen, Germany
}

\begin{abstract}
Seven strains of the genus Sphaerotilus were obtained from natural thermal sulfide (strains $\mathrm{D}-501^{\top}$, D-502, D-504, D-505 and D-507) and low-temperature ferrous (strain $\mathrm{HS}^{\top}$ ) springs and from an activated sludge system (strain D-380). These Sphaerotilus isolates and strains of Sphaerotilus natans obtained from the DSMZ (S. natans DSM $6575^{\top}$, DSM 565 and DSM 566) were studied using a polyphasic taxonomic approach. All strains had Q-8 as the major quinone and $\mathrm{C}_{16: 1} \omega 7$, $\mathrm{C}_{16: 0}$ and $\mathrm{C}_{18: 1} \omega 7$ as the major fatty acids. The DNA-DNA hybridization results and 16S rRNA, $h s p 60$ and gyrB gene sequencing experiments showed that isolates D-501 ${ }^{\top}, \mathrm{D}-502, \mathrm{D}-504, \mathrm{D}-505$, D-507 and D-380 were closely related to the type strain of S. natans DSM $6575^{\top}$. However, strains D-501 ${ }^{\top}, D-502, D-504, D-505$ and D-507 significantly differed from the heterotrophic strain $S$. natans DSM $6575^{\top}$ by their capability for lithotrophic growth with reduced sulfur compounds as an electron donor for energy conservation and some other phenotypic features. For this reason, strains D-501 ${ }^{\top}, \mathrm{D}-502, \mathrm{D}-504, \mathrm{D}-505$ and D-507 merit a separate taxonomic classification at the subspecies level. The name Sphaerotilus natans subsp. sulfidivorans subsp. nov. (type strain $\mathrm{D}-501^{\top}=\mathrm{DSM} 22545^{\top}=$ VKM B-2573 ${ }^{\mathrm{T}}$ ) is proposed. The subspecies Sphaerotilus natans subsp. natans subsp. nov. is automatically created as a result of this proposal. Strain D-380 was phenotypically closely related to S. natans DSM $6575^{\top}$. Strains D-380 and S. natans DSM $6575^{\top}$ were assigned to the subspecies Sphaerotilus natans subsp. natans subsp. nov. (type strain DSM $6575^{\top}=$ ATCC $13338^{\top}$ ). The $16 \mathrm{~S}$ rRNA, $h s p 60$ and gyrB gene sequences obtained for strains $\mathrm{HS}^{\top}$ and DSM 565 showed very low sequence similarity values of $97.3 \%, 89.7 \%$ and $88.4 \%$, respectively, with $S$. natans DSM $6575^{\top}$. Strain $\mathrm{HS}^{\top}$ shared $99 \%$ DNA-DNA relatedness with strain
\end{abstract}

The GenBank/EMBL/DDBJ accession numbers for the $16 \mathrm{~S}$ rRNA gene sequences of strains $\mathrm{HS}^{\top}$, Sphaerotilus natans DSM $6575^{\top}$, DSM $566^{\top}$, DSM 565, D-501', D-507 and D-380 are EU636006, EU642571, GU591795, GU591794, FJ871054, FJ871053 and GU591793, respectively. The accession numbers for the gyrB gene sequences of strains $\mathrm{HS}^{\top}$, Sphaerotilus natans DSM $6575^{\top}, \mathrm{DSM} 566^{\top}, \mathrm{DSM} 565, \mathrm{D}-501^{\top}, \mathrm{D}-507$ and D-380 are FJ161075, FJ032203, GU591797, GU591798, GU734705, GU734704 and GU734706, respectively. The accession numbers for the hsp60 gene sequences of strains $\mathrm{HS}^{\top}$, Sphaerotilus natans DSM 6575 ${ }^{\top}$, DSM 566 ${ }^{\top}$, DSM 565, D-501 ${ }^{\top}$, D-507 and D-380 are FJ167405, FJ167404, GU591796, GU591799, FJ871056, FJ871057 and GU734707, respectively.

Supplementary figures and tables are available with the online version of this paper. 
DSM 565 and $48 \%$ with S. natans DSM $6575^{\top}$. The $16 \mathrm{~S}$ rRNA, $h s p 60$ and gyrB gene sequence similarities between strain DSM $566^{\top}$ and S. natans DSM $6575^{\top}$ were $97.5 \%, 91.5 \%$ and $87.0 \%$, respectively. Strain DSM $566^{\top}$ had $52 \%$ DNA-DNA relatedness to S. natans DSM $6575^{\top}$ and shared $44 \%$ DNA-DNA similarity with strain $\mathrm{HS}^{\top}$. The creation of two novel species is proposed, Sphaerotilus montanus sp. nov. for strains $\mathrm{HS}^{\top}$ and DSM 565 (type strain $\mathrm{HS}^{\top}=\mathrm{DSM}$ $21226^{\top}=$ VKM B-2519 ${ }^{\top}$ ) and Sphaerotilus hippei sp. nov. for strain DSM $566^{\top}$ (type strain DSM $566^{\top}=$ ATCC $\left.29330^{\top}\right)$. Emended descriptions of the genus Sphaerotilus and of Sphaerotilus

natans are presented.

The filamentous organoheterotrophic bacteria, which are affiliated with the genus Sphaerotilus within the class Betaproteobacteria, are widespread in various shallow natural freshwater habitats such as marshy waters, rivers and ponds (Stokes, 1954; Dondero, 1961; van Veen et al., 1978) and anthropogenic ecosystems such as domestic and industrial sewage and activated sludge systems (Dondero, 1961; Eikelboom, 1975; Kämpfer, 1997, 1998; Pellegrin et al., 1999). Numerous isolates of members of the genus Sphaerotilus obtained from various ecosystems and geographical regions represent a taxonomically and phylogenetically homogeneous group. Comparative sequence analysis of $16 \mathrm{~S}$ rRNA genes from the majority of Sphaerotilus isolates has demonstrated that they have a high, similarity to each other and to the 16S rRNA gene sequence of the single recognized species within the genus Sphaerotilus, Sphaerotilus natans DSM 6575 ${ }^{\mathrm{T}}$ (99.6-99.9\% similarity) (Corstjens \& Muyzer, 1993; Siering \& Ghiorse, 1996; Ludwig et al., 1998; Pellegrin et al., 1999; Chernousova et al., 2008). The similarity of the cellular fatty acid composition and quinone types of isolates of the genus Sphaerotilus has also been noted. Although the chemotaxonomic and phylogenetic properties of a number of Sphaerotilus isolates were similar, significant physiological differences between the Sphaerotilus strains isolated from different habitats and Sphaerotilus natans DSM $6575^{\mathrm{T}}$ have been detected (Kämpfer, 1997, 1998; Pellegrin et al., 1999; Gridneva et al., 2009). Members of the genus Sphaerotilus obtained from paper mill slimes were capable of metabolizing complex polysaccharides, polyalcohols or organic acids as carbon sources (Pellegrin et al., 1999). In natural habitats, $S$. natans forms mats with iron oxide depositions in sheaths and therefore it is considered a typical representative of the heterotrophic iron bacteria (Stokes, 1954; Dondero, 1961; van Veen et al., 1978). Recently, stable bacterial communities with a clear domination of representatives of the genus Sphaerotilus have been found in the sulfur mats of various sulfide springs of the North Caucasus, Russia (Chernousova et al., 2008; Gridneva et al., 2009). In contrast to known S. natans strains, these novel Sphaerotilus strains presented atypical characteristics such as the ability for both organoheterotrophic and lithotrophic growth with reduced sulfur compounds as electron donor for energy conservation (Gridneva et al., 2009). These Sphaerotilus strains were closely related to S. natans DSM $6575^{\mathrm{T}}(99.9 \% 16 \mathrm{~S}$ rRNA gene sequence similarity in the $500 \mathrm{nt}$ region sequenced) (Chernousova et al., 2008). Earlier phylogenetic investigations of numerous isolates of the genus Sphaerotilus were performed using analysis of only the 16S rRNA gene sequences. It is well known that $16 \mathrm{~S}$ rRNA gene sequence similarity alone is not sufficient to guarantee species discrimination (Fox et al., 1992). Protein-encoding genes are more variable. In particular, the functional genes $h s p 60$ (coding the $60 \mathrm{kDa}$ chaperonin) and $g y r B$ (coding the subunit B protein of DNA gyrase) can be used as additional phylogenetic markers because they allow better discrimination of taxa, especially at the species and strain level (Yamamoto \& Harayama, 1998; Kwok et al., 1999; Blackwood et al., 2000). Taking into account the abovementioned metabolic heterogeneity, it is possible to speculate that the genus Sphaerotilus may encompass further diverse novel species and subspecies.

In this study, a comparative analysis of seven novel strains of the genus Sphaerotilus is presented. The novel strains were obtained from various habitats and strains of $S$. natans were obtained from the DSMZ. The study was conducted by means of a polyphasic approach including $16 \mathrm{~S}$ rRNA, hsp60 and gyrB gene sequencing, DNADNA hybridization experiments and extensive phenotypic characterization.

Pure cultures of iron-oxidizing bacteria, which were morphologically similar to representatives of the genus Sphaerotilus, were isolated from natural habitats and a wastewater treatment plant. Strains D-501 ${ }^{\mathrm{T}}, \mathrm{D}-502, \mathrm{D}-504$, D-505 and D-507 were isolated from a sulfur mat of a sulfide spring, Petushok spring. The temperature was 34$37^{\circ} \mathrm{C}$. The sulfide content at different times of observation varied from 2 to $11 \mathrm{mg} \mathrm{S}^{2-} \mathrm{l}^{-1}$. The oxygen content varied from 0.1 to $0.5 \mathrm{mg} \mathrm{l}^{-1}$ and the $\mathrm{pH}$ was 7.5-7.6. Strain $\mathrm{HS}^{\mathrm{T}}$ was obtained from a friable deposit of iron oxides that had accumulated on the outflow of the ferriferous spring. The iron content was $0.6-1.8 \mathrm{mg} \mathrm{l}^{-1}$, the $\mathrm{pH}$ was $7.2-7.5$ and the water temperature was $11{ }^{\circ} \mathrm{C}$. The total water mineral content did not exceed 1.6-2.0 $\mathrm{g} \mathrm{l}^{-1}$. Both springs were located in the discharge region of the deep underground waters of the Psekups mineral water deposit of the North Caucasus. Strain D-380 was isolated from activated sludge in a wastewater treatment plant in Voronezh, Russia. The temperature was $25{ }^{\circ} \mathrm{C}$ and the $\mathrm{pH}$ was 7.5. The type strain of S. natans, DSM $6575^{\mathrm{T}}$, and strains DSM 565 and DSM 
$566^{\mathrm{T}}$ were obtained from the German Collection of Microorganisms and Cell Cultures (DSMZ). The full list of the Sphaerotilus strains investigated and their origin is presented in Table 1.

The cultures were maintained and their physiological and biochemical characteristics were investigated in a medium containing the following $\left(\mathrm{mg} \mathrm{l}^{-1}\right):\left(\mathrm{NH}_{4}\right)_{2} \mathrm{SO}_{4}, 100$; $\mathrm{CaCl}_{2}, 50 ; \mathrm{MgSO}_{4} .7 \mathrm{H}_{2} \mathrm{O}, 100$; sodium lactate, 200; $\mathrm{Na}_{2} \mathrm{~S}_{2} \mathrm{O}_{3}, 1000$ or $\mathrm{Na}_{2} \mathrm{~S} .9 \mathrm{H}_{2} \mathrm{O}, 100$ and $10 \%$ phosphate buffer, $10 \mathrm{ml}$; distilled water, $1 \mathrm{l}$, plus vitamins and trace elements (Pfennig \& Lippert, 1966) at $\mathrm{pH}$ 7.5. In the medium used for biomass accumulation, the lactate content was increased to $0.5 \mathrm{~g} \mathrm{l}^{-1}$ and peptone $\left(1 \mathrm{~g} \mathrm{l}^{-1}\right)$ was added. Strain $\mathrm{HS}^{\mathrm{T}}$ was isolated on Veen medium, which contained complexed organic $\mathrm{Fe}^{2+}$ as ammonia citric acid iron (van Veen et al., 1978). Colonies of all strains in Veen medium were rusty coloured with fibrous edges and were $2-5 \mathrm{~mm}$ in size. Cell morphology was observed with a light microscope (CX 4; Olympus) equipped with a phase-contrast device and by transmission electron microscopy (JEM-100C; JEOL) with an accelerating voltage of $60 \mathrm{kV}$. Cells were straight Gram-negative rods, arranged in chains within sheaths. Swarmers released from one end of the filaments were motile by means of bundles of polar flagella. Sheaths were encrusted by ferric oxide $\mathrm{Fe}^{3+}$ when the cultures were grown in the media containing $\mathrm{Fe}^{2+}$. Cells of strains D-501 ${ }^{\mathrm{T}}, \mathrm{D}-502, \mathrm{D}-504$, D-505 and D-507 were able to accumulate sulfur granules intracellularly when the cultures were grown in media containing sulfide (see Supplementary Fig. S1 in IJSEM Online). The filaments were not mobile. The filaments could be attached to a solid substrate by means of holdfasts. Cells contained granules of poly- $\beta$-hydroxyalkanoates as reserve material.

The novel strains were examined for a range of phenotypic and biochemical properties using standard methods (Gerhardt et al., 1981). The physiological properties of the novel Sphaerotilus strains and the strains of S. natans from the DSMZ collection were determined by cultivation in the mineral media described above containing a single compound as the carbon source. Comparisons of the morphological and physiological properties of the novel Sphaerotilus strains and S. natans DSM $6575^{\mathrm{T}}$ are shown in Table 2 and Table 3. All strains had a respiratory type of metabolism and were not able to use fumarate or nitrate as electron acceptor under anaerobic conditions. All of the strains investigated, except for strain DSM $566^{\mathrm{T}}$, reduced nitrate to nitrite. Strain DSM $566^{\mathrm{T}}$ was not capable of assimilatory nitrate reduction. Casein and starch were not hydrolysed. Gelatin was not liquefied. No formation of pigments was observed during growth on aromatic amino acids. Indole was not formed. No growth took place in the presence of $3 \%(\mathrm{w} / \mathrm{v}) \mathrm{NaCl}$. Strains D-501 ${ }^{\mathrm{T}}, \mathrm{D}-502, \mathrm{D}-504$, D-505 and D-507 were capable of lithoheterotrophic growth with utilization of thiosulfate or sulfide as electron donor for energy metabolism. The differences in the end products, rates of thiosulfate oxidation and activities of the key enzymes of oxidative sulfur metabolism were determined among the strains. All strains except D-507 were capable of lithoheterotrophic growth with reduced sulfur compounds used as electron donors for energy metabolism only under microaerobic conditions. In order

Table 1. List of strains used in this study and their origin

ND, No data.

\begin{tabular}{|c|c|c|c|c|c|}
\hline Organism & Strain & New designation & $\begin{array}{c}\text { GenBank } \\
\text { accession no. }\end{array}$ & Source & Reference \\
\hline Sphaerotilus natans & DSM $6575^{\mathrm{T}}$ & $\begin{array}{l}\text { S. natans subsp. } \\
\text { natans subsp. nov. }\end{array}$ & EU642571 & Polluted waters & Kützing (1833) \\
\hline Sphaerotilus sp. & D-380 & $\begin{array}{l}\text { S. natans subsp. } \\
\text { natans subsp. nov. }\end{array}$ & GU591793 & $\begin{array}{l}\text { Activated sludge system, } \\
\text { Voronezh, Russia }\end{array}$ & This study \\
\hline Sphaerotilus sp. & $\mathrm{D}-501^{\mathrm{T}}$ & $\begin{array}{l}\text { S. natans subsp. } \\
\text { sulfidivorans subsp. nov. }\end{array}$ & FJ871054 & $\begin{array}{l}\text { Thermal sulfide spring, } \\
\text { North Caucasus, Russia }\end{array}$ & $\begin{array}{l}\text { Chernousova et al. (2008); } \\
\text { Gridneva et al. (2009) }\end{array}$ \\
\hline Sphaerotilus sp. & D-502 & $\begin{array}{l}\text { S. natans subsp. } \\
\text { sulfidivorans subsp. nov. }\end{array}$ & ND & $\begin{array}{l}\text { Thermal sulfide spring, } \\
\text { North Caucasus, Russia }\end{array}$ & $\begin{array}{l}\text { Chernousova et al. (2008); } \\
\text { Gridneva et al. (2009) }\end{array}$ \\
\hline Sphaerotilus sp. & D-504 & $\begin{array}{l}\text { S. natans subsp. } \\
\text { sulfidivorans subsp. nov. }\end{array}$ & $\mathrm{ND}$ & $\begin{array}{l}\text { Thermal sulfide spring, } \\
\text { North Caucasus, Russia }\end{array}$ & $\begin{array}{c}\text { Chernousova et al. (2008); } \\
\text { Gridneva et al. (2009) }\end{array}$ \\
\hline Sphaerotilus sp. & D-505 & $\begin{array}{l}\text { S. natans subsp. } \\
\text { sulfidivorans subsp. nov. }\end{array}$ & ND & $\begin{array}{l}\text { Thermal sulfide spring, } \\
\text { North Caucasus, Russia }\end{array}$ & $\begin{array}{l}\text { Chernousova et al. (2008); } \\
\text { Gridneva et al. (2009) }\end{array}$ \\
\hline Sphaerotilus sp. & D-507 & $\begin{array}{l}\text { S. natans subsp. } \\
\text { sulfidivorans subsp. nov. }\end{array}$ & FJ871053 & $\begin{array}{l}\text { Thermal sulfide spring, } \\
\text { North Caucasus, Russia }\end{array}$ & $\begin{array}{c}\text { Chernousova et al. (2008); } \\
\text { Gridneva et al. (2009) }\end{array}$ \\
\hline Sphaerotilus sp. & $\mathrm{HS}^{\mathrm{T}}$ & S. montanus sp. nov. & EU636006 & $\begin{array}{l}\text { Low-temperature ferrous } \\
\text { spring, North Caucasus, Russia }\end{array}$ & This study \\
\hline Sphaerotilus natans & DSM 565 & S. montanus sp. nov. & GU591794 & Pond water, Germany & ND \\
\hline Sphaerotilus natans & DSM $566^{\mathrm{T}}$ & S. hippei sp. nov. & GU591795 & Pond water, Germany & ND \\
\hline
\end{tabular}


Table 2. Differential characteristics of Sphaerotilus natans

Strains: 1, DSM 6575 ${ }^{\mathrm{T}}$; 2, D-380 (=VKM B-2579); 3, D-501 ${ }^{\mathrm{T}}$ (=DSM 22545); 4, D-502 (=VKM B-2575); 5, D-504 (=VKM B-2576); 6, D-505 (=VKM B-2577); 7, D-507 (=DSM 22546). All strains utilize the following as sole carbon and energy sources: succinate, lactate, pyruvate, malate, oxaloacetate, oxalate, sorbitol, 2-oxoglutarate, malonate, glucose, sucrose, galactose, maltose, fructose, glycerol, ethanol, glutamate, proline, aspartate, alanine, phenylalanine, asparagine, ornithine, peptone, yeast extract and casein hydrolysate. Formate, glycolate, glyoxylate, salicylate, lysine and methionine are not utilized. Ammonium salts, nitrates, aspartate, glutamate, cysteine, peptone, yeast extract and casein hydrolysate may be used as a nitrogen source; methionine is not used. +, Positive; -, negative; ND, no data available.

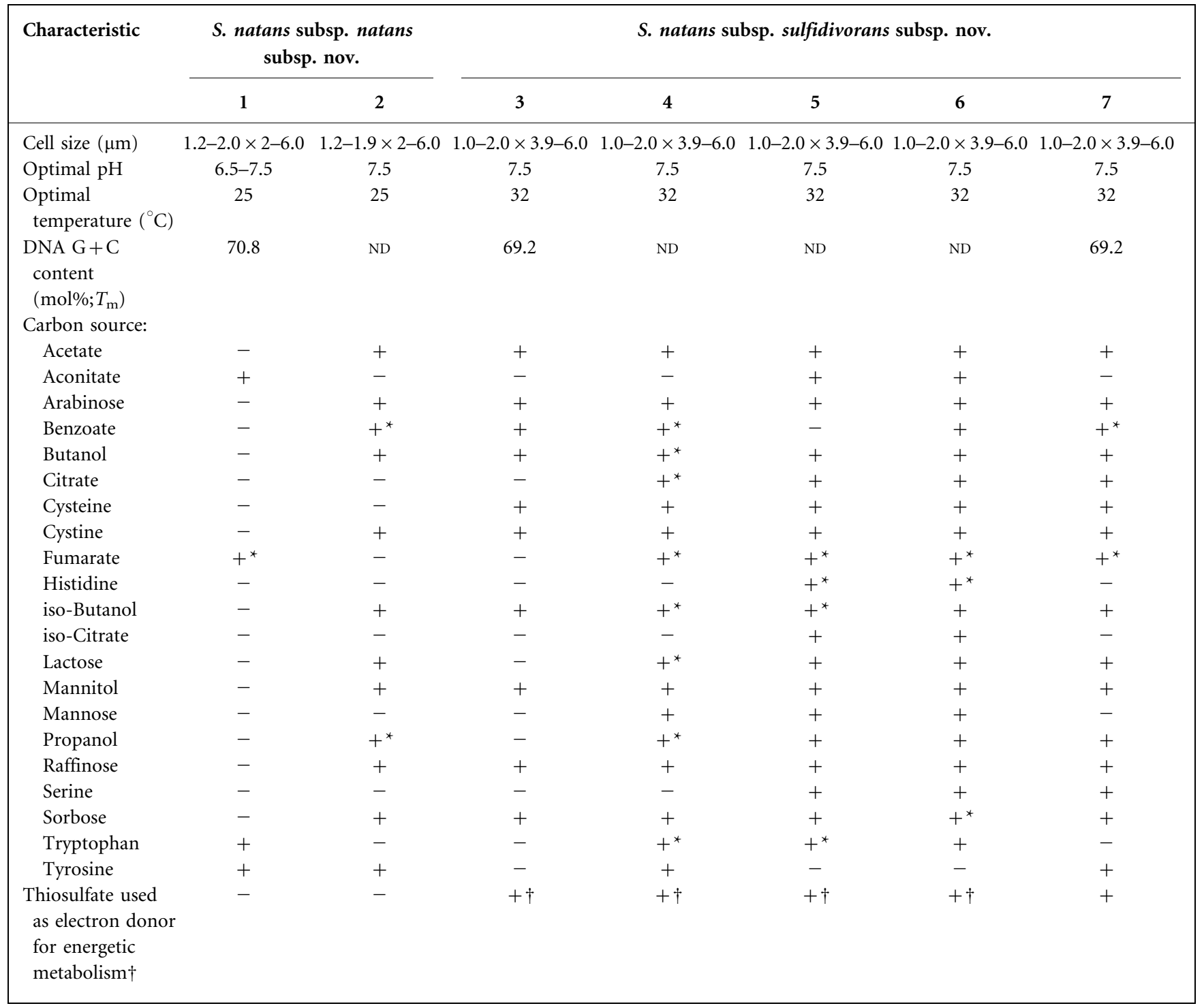

${ }^{\star}$ Poor growth.

†Only under microaerobic conditions.

to create microaerobic conditions, rubber-stoppered $50 \mathrm{ml}$ vials with $10 \mathrm{ml}$ medium were flushed with filter-sterilized argon. A calculated volume of sterile air was then injected into the vials to create a final oxygen concentration of $5 \%$ in the gas phase. Strain D-507 was capable of thiosulfate oxidation regardless of the oxygenation regime. The ability of the strains to conduct lithotrophic growth was confirmed by using enzymic methods and polarographic analysis (Gridneva et al., 2009). Oxidation of sulfide was accompanied by the deposit of sulfur granules within the cells.

Analysis of fatty acids was conducted on a specialized chromatographic Microbial Identification System (Sherlock) (MIDI Inc.) according to standard protocols (Stead et al., 1992). The fatty acid composition of the cell 
Table 3. Differential characteristics of the type strains of species of the genus Sphaerotilus

Strains: 1, S. natans DSM $6575^{\mathrm{T}}$; 2, S. montanus sp. nov. HS ${ }^{\mathrm{T}}$ (=DSM $21226^{\mathrm{T}}$; the properties of strains $\mathrm{HS}^{\mathrm{T}}$ and DSM 565 were highly similar; therefore, only data for strain $\mathrm{HS}^{\mathrm{T}}$ are presented); 3, S. hippei sp. nov. DSM $566^{\mathrm{T}}$. Succinate, lactate, pyruvate, malate, oxaloacetate, 2-oxoglutarate, malonate, glucose, sucrose, maltose, fructose, glycerol, ethanol, glutamate, proline, peptone, yeast extract and casein hydrolysate are utilized as sole carbon and energy sources by all strains. Formate, glycolate, salicylate, iso-citrate, raffinose, cysteine, cystine, lysine, serine and methionine are not utilized. Ammonium salts, nitrates, aspartate, glutamate, cysteine, peptone, yeast extract and casein hydrolysate may be used as a nitrogen source; methionine is not used. +, Positive; -, negative.

\begin{tabular}{|c|c|c|c|}
\hline Characteristic & 1 & 2 & 3 \\
\hline Cell size $(\mu \mathrm{m})$ & $1.2-2.0 \times 2-6.0$ & $0.8-1.4 \times 3.3-6.0$ & $0.7-1.5 \times 2.0-6.2$ \\
\hline Optimal pH & $6.5-7.5$ & 7.5 & 7.0 \\
\hline Optimal temperature $\left({ }^{\circ} \mathrm{C}\right)$ & 25 & $26-27$ & $26-27$ \\
\hline DNA G $+\mathrm{C}$ content $\left(\mathrm{mol} \% ; T_{\mathrm{m}}\right)$ & 70.8 & 67.8 & 69.0 \\
\hline \multicolumn{4}{|l|}{ Carbon source: } \\
\hline Acetate & - & - & + \\
\hline Aconitate & + & + & - \\
\hline Alanine & + & + & - \\
\hline Arabinose & - & + & + \\
\hline Asparagine & + & - & - \\
\hline Aspartate & + & + & - \\
\hline Benzoate & - & + & - \\
\hline Butanol & - & + & + \\
\hline Citrate & - & + & + \\
\hline Fumarate & $+^{*}$ & + & - \\
\hline Galactose & + & - & - \\
\hline Glyoxylate & - & + & + \\
\hline Histidine & - & - & + \\
\hline Iso-butanol & - & - & + \\
\hline Lactose & - & + & - \\
\hline Mannitol & - & + & - \\
\hline Mannose & - & + & + \\
\hline Ornithine & + & + & - \\
\hline Oxalate & $+^{*}$ & + & - \\
\hline Petroleum products $\dagger$ & + & - & - \\
\hline Phenylalanine & + & + & - \\
\hline Propanol & - & + & + \\
\hline Sorbitol & + & + & - \\
\hline Sorbose & - & + & + \\
\hline Tryptophan & + & + & - \\
\hline Tyrosine & + & - & - \\
\hline
\end{tabular}

${ }^{\star}$ Poor growth.

$\dagger$ Petroleum products are oil and petroleum.

membranes of the novel strains is shown in Table 4. All strains possessed $C_{16: 1} \omega 7, C_{16: 0}$ and $C_{18: 1} \omega 7$ as the predominant fatty acids.

Genomic DNA was extracted from cells of the test strains according to the protocol of Ausubel et al. (1994), with slight modifications, and by the freeze-thaw method (Bej et al., 1991). The 16S rRNA gene of all the strains and $S$. natans DSM $6575^{\mathrm{T}}$ was amplified using the primers $27 \mathrm{f}$ (5'-AGAGTTTGATCCTGGCTCAG-3') and 1492r (5' -TACGGYTACCTTGTTACGACTT-3') (Lane, 1991; Medlin et al., 1988). The PCR products were sequenced by using an automatic sequencer (CEQ2000 XL; Beckman Coulter). Alignment of the $16 \mathrm{~S}$ rRNA gene sequences (1400 nt) was carried out using the CLUSTAL_X software package (Thompson et al., 1997). An evolutionary-distance matrix was calculated using the correction of Jukes \& Cantor (1969). The phylogenetic trees were constructed by using the neighbour-joining (Saitou \& Nei, 1987) and the maximum-likelihood (Guindon \& Gascuel, 2003) methods, with the 16S rRNA gene sequence of Alcaligenes faecalis subsp. faecalis ATCC $8750^{\mathrm{T}}$ as an outgroup. Bootstrap analyses of the neighbour-joining and the maximumlikelihood methods were based on 1000 and 100 resamplings, 
Table 4. Comparison of the cellular fatty acid contents of the type strains of species and subspecies of the genus Sphaerotilus

Strains: 1 , S. natans subsp. natans subsp. nov. DSM $6575^{\mathrm{T}} ; 2$, S. natans subsp. sulfidivorans subsp. nov. D-501 ${ }^{\mathrm{T}}\left(=\mathrm{DSM} 22545^{\mathrm{T}}\right) ; 3, S$. montanus sp. nov. $\mathrm{HS}^{\mathrm{T}}$ (=DSM $21226^{\mathrm{T}}$ ); 4, S. hippei sp. nov. DSM $566^{\mathrm{T}}$. - , Not detected; tr, trace peak $($ area $<0.5 \%)$.

\begin{tabular}{|lcccc|}
\hline Fatty acid & $\mathbf{1}$ & $\mathbf{2}$ & $\mathbf{3}$ & $\mathbf{4}$ \\
\hline $\mathrm{C}_{12: 0}$ & 1.4 & 0.9 & 1.0 & 2.0 \\
$\mathrm{C}_{10: 0} 3-\mathrm{OH}$ & 1.2 & 1.2 & 0.6 & 0.6 \\
$\mathrm{C}_{14: 1} \omega 5$ & 0.7 & 0.6 & 5.4 & $\operatorname{tr}$ \\
$\mathrm{C}_{14: 1} \omega 3$ & - & - & - & $\operatorname{tr}$ \\
$\mathrm{C}_{14: 0}$ & $\operatorname{tr}$ & $\operatorname{tr}$ & - & 1.8 \\
$\mathrm{C}_{15: 1} \omega 6$ & $\operatorname{tr}$ & - & - & $\operatorname{tr}$ \\
$\mathrm{C}_{15: 0}$ & $\operatorname{tr}$ & - & 0.8 & $\operatorname{tr}$ \\
$\mathrm{C}_{16: 1} \omega 7$ & 58.2 & 68.6 & 52.2 & 56.2 \\
$\mathrm{C}_{16: 1} \omega 5$ & $\operatorname{tr}$ & 0.8 & 0.8 & $\operatorname{tr}$ \\
$\mathrm{C}_{16: 0}$ & 18.6 & 12.0 & 30.7 & 32.0 \\
$\mathrm{C}_{17: 1} \omega 6$ & - & - & $\operatorname{tr}$ & - \\
$\mathrm{C}_{18: 1} \omega 9$ & $\operatorname{tr}$ & $\operatorname{tr}$ & $\operatorname{tr}$ & $\operatorname{tr}$ \\
$\mathrm{C}_{18: 1} \omega 7$ & 18.6 & 14.2 & 5.6 & 6.0 \\
$\mathrm{C}_{18: 0}$ & $\operatorname{tr}$ & 0.8 & $\operatorname{tr}$ & 0.6 \\
$11-\mathrm{Me}-\mathrm{C}_{18: 1}$ & 0.7 & 0.5 & 2.6 & $\operatorname{tr}$ \\
& & & & \\
\hline
\end{tabular}

respectively. The TREECON software package was used for the analysis (Van de Peer \& De Wachter, 1994) in combination with the PHYML software package (Felsenstein, 1993). The phylogenetic trees based on 16S rRNA gene sequences constructed by using the neighbour-joining and the maximum-likelihood methods are shown in Fig. 1 and Supplementary Fig. S2 (available in IJSEM Online), respectively. Protein-encoding genes are regarded as more useful for species discrimination. Therefore, the functional genes hsp60 and gyrB were used as additional phylogenetic markers to discriminate the taxa at the species and strain level (Yamamoto \& Harayama, 1998; Kwok et al., 1999; Blackwood et al., 2000). The $h s p 60$ gene was amplified from bacterial genomic DNA of all investigated strains using the universal $h s p 60$ degenerate primers H1612 (5'-GAIIIIGCIGGYGACGGYACSACSAC-3') and H1613 (5'-CGRCGRTCRCCGAAGCCSGGIGCCTT- $3^{\prime}$ ) and PCR conditions as described by Hill et al. (2006). The gyrB gene was amplified by PCR using universal gyrB degenerate primers Up1 ( $5^{\prime}$ GAAGTCATCATGACCGTTCTGCAYGCNGGNGGNAARTTYGA-3') and Up2r (5'-AGCAGGGTACGGATGTGCGAGCCRTCNACRTCNGCRTCNGTCAT-3') and the conditions as described by Yamamoto and Harayama (1995). The partial hsp60 (550 bp) and gyrB (1200 bp) gene sequences obtained for the Sphaerotilus strains were aligned as described for the 16S rRNA gene sequences.

Strains D-501 ${ }^{\mathrm{T}}, \mathrm{D}-502, \mathrm{D}-504, \mathrm{D}-505$ and D-507 have previously been compared by ERIC-PCR (Chernousova et al., 2008). The ERIC profiles of all the Sphaerotilus strains were identical, indicating the absence of population heterogeneity among the strains. However, strain D-507 was found to be physiologically different from the other strains of its group. Therefore, the use of strain D- $501^{\mathrm{T}}$ (as the reference strain of the group) and strain D-507 for the comparative analysis of the $16 \mathrm{~S}$ rRNA, $h s p 60$ and $\operatorname{gyrB}$ genes and for the performance of the DNA-DNA hybridization experiments seemed appropriate. S. natans strains IF4, IF5, IF15 and IF9 isolated from paper mill slimes and S. natans strain ATCC 15291 were also included in the comparative analysis of the 16S rRNA genes. The nearly full-length $16 \mathrm{~S}$ rRNA gene sequence for $S$. natans strain ATCC 15291 (=NBRC 13543) was available only from the database of the NITE Biological Research Center (NBRC). The nearly full-length 16S rRNA gene sequences for the $S$.

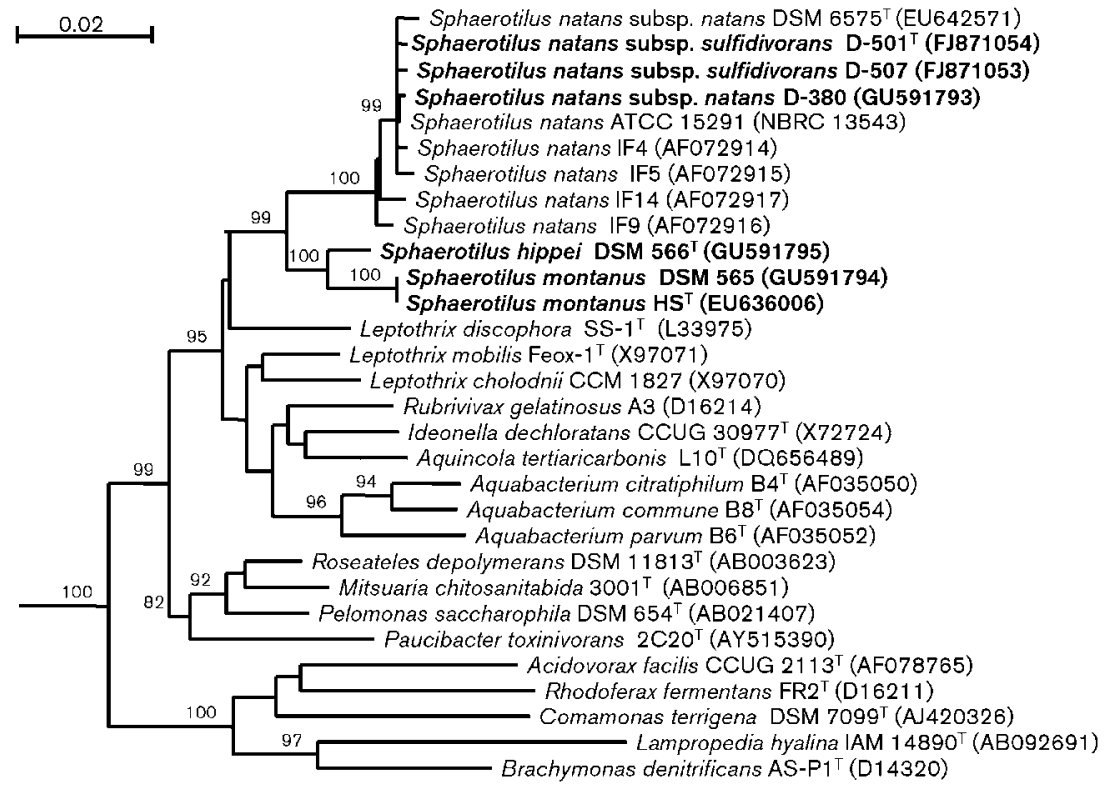

Fig. 1. Neighbour-joining phylogenetic tree based on 16S rRNA gene sequences, showing the position of the strains of the genus Sphaerotilus among their closest relatives. Numbers at the branch nodes are bootstrap values, expressed as a percentage of 1000 replicates (only values $>70 \%$ are shown). The tree was rooted using Alcaligenes faecalis subsp. faecalis ATCC $8750^{\top}$ as an outgroup. Bar, 0.02 substitutions per nucleotide position. 
natans strains from the paper mill slimes were retrieved from GenBank.

Analysis of $16 \mathrm{~S}$ rRNA, hsp60 and gyrB gene sequences of isolates $\mathrm{D}-501^{\mathrm{T}}$ and $\mathrm{D}-380$ revealed an extremely close phylogenetic relationship to $S$. natans DSM $6575^{\mathrm{T}}$ (see Supplementary Table S1). Strains $\mathrm{D}-501^{\mathrm{T}}$ and $\mathrm{D}-507$ were identical based on analysis of these phylogenetic markers. The 16S rRNA gene sequence similarities between strains $\mathrm{D}-501^{\mathrm{T}}, \mathrm{D}-380$ and the reference strains of $S$. natans (ATCC 15291 and the strains from paper mill slimes) ranged from 99.7 to $99.9 \%$. This suggested that strains D-501 ${ }^{\mathrm{T}}, \mathrm{D}-507$ and D-380 were members of the same species, S. natans, within the genus Sphaerotilus.

The $16 \mathrm{~S}$ rRNA, hsp60 and gyrB gene sequences obtained for strains $\mathrm{HS}^{\mathrm{T}}$, DSM 565 and DSM $566^{\mathrm{T}}$ showed very low sequence similarity values when compared with those of S. natans DSM $6575^{\mathrm{T}}$ (Supplementary Table S1). Strain $\mathrm{HS}^{\mathrm{T}}$ and DSM 565 were found to be identical based on analysis of these phylogenetic markers. Strain DSM $566^{\mathrm{T}}$ shared 98.6, 91.6 and $91.7 \%$ similarity in the $16 \mathrm{~S}$ rRNA, hsp60 and gyrB gene sequences with strain $\mathrm{HS}^{\mathrm{T}}$. The noticeable phylogenetic differences between strains DSM $566^{\mathrm{T}}$ and $\mathrm{HS}^{\mathrm{T}}$ and between these novel strains and $S$. natans DSM $6575^{\mathrm{T}}$ suggested that strains DSM $566^{\mathrm{T}}$ and $\mathrm{HS}^{\mathrm{T}}$ may represent two novel species of the genus Sphaerotilus.

DNA $\mathrm{G}+\mathrm{C}$ content was determined by the thermal denaturation method as described previously (Owen \& Lapage, 1976). The DNA G $+C$ content of the novel strains was $67.8-70.8 \mathrm{~mol} \%$. Levels of DNA-DNA relatedness were determined by measuring the renaturation rates of the denatured DNAs at the optimal renaturation temperatures as recommended by De Ley et al. (1970). A spectrophotometer (SP 1800; Pye Unicam) equipped with a thermoprogrammer and hermetically sealed thermocuvettes was used. DNA-DNA hybridization studies of strains D-380, $\mathrm{D}-501^{\mathrm{T}}, \mathrm{D}-504, \mathrm{D}-507$ and S. natans DSM $6575^{\mathrm{T}}$ revealed a similarity value of $80-98 \%$, indicating a clear affiliation to the species $S$. natans according to the taxonomic guidelines proposed by Wayne et al. (1987). Strains $\mathrm{HS}^{\mathrm{T}}$ and DSM $566^{\mathrm{T}}$ showed $44 \%$ DNA-DNA relatedness and had relatedness values of $48 \%$ and $52 \%$, respectively, with $S$. natans DSM $6575^{\mathrm{T}}$ (see Supplementary Table S2 in IJSEM Online).

Based on phenotypic, chemotaxonomic and phylogenetic characteristics, strains $\mathrm{HS}^{\mathrm{T}}$ and DSM 565 represent a novel species within the genus Sphaerotilus for which the name Sphaerotilus montanus sp. nov. is proposed. The type strain is $\mathrm{HS}^{\mathrm{T}}$. Strain DSM $566^{\mathrm{T}}$ also represents a separate novel species, for which the name Sphaerotilus hippei sp. nov. is proposed.

The DNA-DNA hybridization results, the $16 \mathrm{~S}$ rRNA, $h s p 60$ and $g y r B$ gene sequencing studies and the phenotypic data revealed that the sulfur spring isolates, strains $\mathrm{D}-501^{\mathrm{T}}, \mathrm{D}-$ 502, D-504, D-505 and D-507, were closely related to $S$. natans DSM $6575^{\mathrm{T}}$, but they significantly differed from earlier known strains of $S$. natans by their capability for lithotrophic growth with reduced sulfur compounds and their ability to thrive in thermal sulfide habitats, and in some additional phenotypic characteristics. For this reason, strains D-501 ${ }^{\mathrm{T}}$, D-502, D-504, D-505 and D-507 represent a separate taxon at the subspecies level and thus the name Sphaerotilus natans subsp. sulfidivorans subsp. nov. is proposed, with strain $\mathrm{D}-501^{\mathrm{T}}$ as the type strain. The proposal of the novel subspecies automatically creates the subspecies Sphaerotilus natans subsp. natans subsp. nov., with strain DSM $6575^{\mathrm{T}}$ as the type strain and strain D-380 as an additional member of this subspecies. Strain ATCC 15291 and the IF group of Sphaerotilus strains isolated from paper mill slimes have been previously assigned to the species S. natans (Kämpfer, 1997; Pellegrin et al., 1999), but additional physiological and phylogenetic studies will be required to clarify the subspecies affiliation of these strains.

\section{Emended description of the genus Sphaerotilus Kützing, 1833 (Approved Lists 1980)}

In addition to organoheterotrophic growth, some strains (D-501 ${ }^{\mathrm{T}}, \mathrm{D}-502, \mathrm{D}-504, \mathrm{D}-505$ and D-507) are capable of both mixotrophic growth, with simultaneous utilization of organic substrates and sulfur compounds as electron donors for energy metabolism, and lithoheterotrophic growth using reduced sulfur compounds in energy metabolism (Gridneva et al., 2009). Oxidation of sulfide is accompanied by deposition of sulfur granules within the cells. Able to develop in natural sulfide thermal springs. The temperature range for growth is $10-40{ }^{\circ} \mathrm{C}$.

\section{Description of Sphaerotilus natans subsp. natans subsp. nov.}

Sphaerotilus natans subsp. natans (na'tans. L. part. adj. natans swimming).

The description is as given by Kützing (1833) (Kämpfer \& Spring, 2005). The type strain is DSM $6575^{\mathrm{T}}$ (=ATCC $13338^{\mathrm{T}}=$ LMG $7172^{\mathrm{T}}$ ).

\section{Description of Sphaerotilus natans subsp. sulfidivorans subsp. nov.}

Sphaerotilus natans subsp. sulfidivorans subsp. nov. (sul.fi. di.vo'rans. N.L. n. sulfidum sulphide; L. part adj. vorans consuming; N.L. part adj. sulfidivorans sulfide-consuming).

Cell morphology is the same as that given for the genus (Kämpfer \& Spring, 2005). Cells are 1.0-2.0 × 3.9-6.0 $\mu \mathrm{m}$. Capable of developing in natural sulfide springs. The temperature range for growth is $15-40{ }^{\circ} \mathrm{C}$, with optimum growth occurring at $32{ }^{\circ} \mathrm{C}$. The $\mathrm{pH}$ range for growth is $6.3-$ 8.5, with optimum growth at $\mathrm{pH}$ 7.5. Chemoorganoheterotrophic; chemolithoheterotrophic; metabolism is respiratory and aerobic. Cells are able to use reduced 
sulfur compounds as electron donors for energy conservation. When grown in a medium with sulfide and under the natural conditions of a sulfide spring, granules of elemental sulfur are accumulated. Acetate, lactate, succinate, pyruvate, malate, oxalate, oxaloacetate, 2-oxoglutarate, malonate, glucose, arabinose, galactose, sorbose, raffinose, sucrose, maltose, fructose, glycerol, ethanol, butanol, isobutanol, mannitol, sorbitol, glutamate, aspartate, cysteine, cystine, alanine, phenylalanine, asparagine, proline, ornithine, peptone, yeast extract, casein hydrolysate and petroleum products are utilized as carbon and energy sources. Formate, salicylate, glyoxylate, glycolate, lysine and methionine are not utilized. Peptone, yeast extract, aspartate, glutamate, cysteine, casein hydrolysate, ammonium and nitrate are used as nitrogen sources. Methionine is not used as a nitrogen source. Nitrate is reduced to nitrite. Casein and starch are not hydrolysed; gelatin is not liquefied. Nitrate and fumarate are not used as electron acceptors. Indole is not formed. No growth in the presence of $3 \%(\mathrm{w} / \mathrm{v}) \mathrm{NaCl}$. Positive in tests for oxidase and catalase activities. Pigments are not formed when the organism is grown on a medium containing aromatic amino acids. Acids are not produced from sugars. The major quinone is Q-8. The major fatty acids are $\mathrm{C}_{16: 1} \omega 7$, $\mathrm{C}_{16: 0}$ and $\mathrm{C}_{18: 1} \omega 7$. The $\mathrm{G}+\mathrm{C}$ content of the DNA is $69.2 \mathrm{~mol} \%\left(T_{\mathrm{m}}\right)$.

The type strain, D-501 ${ }^{\mathrm{T}}\left(=\mathrm{DSM} 22545^{\mathrm{T}}=\mathrm{VKM} \mathrm{B}-2573^{\mathrm{T}}\right)$, was isolated from a sulfur mineral thermal spring, located in the foothills of the North Caucasus, Russia.

\section{Description of Sphaerotilus montanus sp. nov.}

Sphaerotilus montanus sp. nov. (mon.ta'nus. L. masc. adj. montanus referring to a mountain, pertaining to an iron spring, located in the foothills of the North Caucasus, Russia, the place from where the strain was isolated).

Straight rods, $0.8-1.4 \times 3.3-6.0 \mu \mathrm{m}$, arranged in chains within sheaths. Gram-negative-staining. The swarmers that are released from one of the ends of the filaments are motile by means of bundles of polar flagella. Possess sheaths with encrustations of ferric oxides. Filaments are not mobile. Branching is absent. Filaments may be attached by means of a holdfast to solid substrates. Cells contain granules of poly- $\beta$-hydroxybutyrate as a reserve material. Colonies with fibrous edges are rusty yellow-coloured due to the deposition of ferric oxides and are $2-5 \mathrm{~mm}$ in size. The temperature range for growth is $7-36{ }^{\circ} \mathrm{C}$, with optimum growth occurring at $28-30{ }^{\circ} \mathrm{C}$. The $\mathrm{pH}$ range for growth is 5.5-8.5, with optimum growth at $\mathrm{pH} 7.5$. Chemoorganotrophic; metabolism is respiratory and aerobic. Lactate, pyruvate, fumarate, oxaloacetate, oxalate, 2-oxoglutarate, malate, malonate, citrate, benzoate, succinate, aconitate, glyoxylate; aspartate, glutamate, phenylalanine, tryptophan, proline, ornithine, alanine; glycerol, ethanol, butanol, propanol, mannitol, sorbitol; lactose, glucose, sorbose, mannose, sucrose, maltose, fructose, arabinose, peptone, yeast extract and casein hydrolysate are utilized as carbon and energy sources. Acetate, formate, salicylate, glycolate, iso-citrate, iso-butanol, galactose, raffinose, cysteine, cystine, lysine, serine, methionine, histidine, asparagine, tyrosine and petroleum products are not utilized. Peptone, yeast extract, aspartate, glutamate, cysteine, casein hydrolysate, ammonium and nitrate are used as nitrogen sources. Methionine is not used as a nitrogen source. Nitrate is reduced to nitrite. Casein and starch are not hydrolysed; gelatin is not liquefied. Nitrate and fumarate are not used as electron acceptors. Indole is not formed. No growth in the presence of $3 \%(\mathrm{w} / \mathrm{v}) \mathrm{NaCl}$ is found. Positive in tests for oxidase and catalase activities. Pigments are not formed when the organism is grown on a medium containing aromatic amino acids. Acids are not formed in the presence of sugars. The major quinone is Q-8. The major fatty acids are $\mathrm{C}_{16: 1} \omega 7, \mathrm{C}_{16: 0}$ and $\mathrm{C}_{18: 1} \omega 7$. The $\mathrm{G}+\mathrm{C}$ content of the DNA is $67.8 \mathrm{~mol} \%$ $\left(T_{\mathrm{m}}\right)$.

The type strain, $\mathrm{HS}^{\mathrm{T}}\left(=\mathrm{DSM} 21226^{\mathrm{T}}=\right.$ VKM B- $\left.2519^{\mathrm{T}}\right)$, was isolated from a ferrous iron-containing cold mountainous spring located in the foothills of the North Caucasus, Russia.

\section{Description of Sphaerotilus hippei sp. nov.}

Sphaerotilus hippei sp. nov. (hip'pe.i. N.L. gen. masc. n. hippei of Hippe, named after H. Hippe, a German microbiologist, who isolated this strain).

Cell morphology is the same as that given for the genus (Kämpfer \& Spring, 2005). Cells are 0.7-1.5 × 2.0-6.2 $\mu \mathrm{m}$. The temperature range for growth is $7-35{ }^{\circ} \mathrm{C}$, with optimum growth occurring at $26-27{ }^{\circ} \mathrm{C}$. The $\mathrm{pH}$ range for growth is 6.3-8.5, with optimum growth at $\mathrm{pH}$ 7.5. Chemoorganotrophic; metabolism is respiratory and aerobic. Acetate, lactate, succinate, pyruvate, malate, oxaloacetate, citrate, 2-oxoglutarate, malonate, glyoxylate, glucose, arabinose, sorbose, mannose, sucrose, maltose, fructose, glycerol, ethanol, propanol, butanol, iso-butanol, glutamate, histidine, proline, peptone, yeast extract and casein hydrolysate are utilized as carbon and energy sources. Formate, fumarate, oxalate, iso-citrate, benzoate, aconitate, mannitol, sorbitol, galactose, raffinose, lactose, serine, aspartate, cysteine, cystine, tryptophan, alanine, phenylalanine, asparagine, tyrosine, ornithine, glycolate, salicylate, lysine, methionine and petroleum products are not utilized. Peptone, yeast extract, aspartate, glutamate, cysteine, casein hydrolysate and ammonium are used as nitrogen sources. Methionine is not used as a nitrogen source. Nitrate is not reduced to nitrite. Casein and starch are not hydrolysed; gelatin is not liquefied. Nitrate and fumarate are not used as electron acceptors. Indole is not formed. No growth in the presence of $3 \%(\mathrm{w} / \mathrm{v}) \mathrm{NaCl}$ is found. Positive in tests for oxidase and catalase activities. Pigments are not formed when the organism is grown on a medium containing aromatic amino acids. Acids are not produced from sugars. The major quinone is Q-8. The major fatty acids are $\mathrm{C}_{16: 1} \omega 7, \mathrm{C}_{16: 0}$ and $\mathrm{C}_{18: 1} \omega 7$. The $\mathrm{G}+\mathrm{C}$ content of the DNA is $69 \mathrm{~mol} \%\left(T_{\mathrm{m}}\right)$. 
The type strain, DSM $566^{\mathrm{T}}\left(=\right.$ ATCC $\left.29330^{\mathrm{T}}\right)$, was isolated by $\mathrm{H}$. Hippe from pond water, Guttingen, Germany.

\section{Acknowledgements}

The authors wish to thank Dr A. M. Lysenko for analysis of the DNA $\mathrm{G}+\mathrm{C}$ contents and DNA-DNA hybridization and Dr G. A. Osipov for performing the cellular fatty acid analysis. This work was supported by grants from the Russian Foundation for Fundamental Research (05-04-48299) and the Program of Presidium of Russian Academy of Sciences 'Molecular and Cell Biology' (07-04-00651).

\section{References}

Ausubel, F. M., Brent, R., Kingston, R. E., Moore, D. D., Seidman, J. G., Smith, J. A. \& Struhl, K. (editors) (1994). Current protocols in Molecular Biology. New York: Wiley.

Bej, A. K., Mahbubani, M. H., Dicesare, J. L. \& Atlas, R. M. (1991). Polymerase chain reaction-gene probe detection of microorganisms by using filter-concentrated samples. Appl Environ Microbiol 57, 35293534.

Blackwood, K. S., He, C., Gunton, J., Turenne, C. Y., Wolfe, J. \& Kabani, A. M. (2000). Evaluation of $r e c A$ sequences for identification of Mycobacterium species. J Clin Microbiol 38, 2846-2852.

Chernousova, E. lu., Akimov, V. N., Gridneva, E. V., Dubinina, G. A. \& Grabovich, M. lu. (2008). [Phylogenetic in situ/ex situ analysis of a sulfur mat microbial community from a thermal sulfide stream in the North Caucasus]. Mikrobiologiia 77, 255-260 (in Russian).

Corstjens, P. \& Muyzer, G. (1993). Phylogenetic analysis of the metal oxidizing bacteria Leptothrix discophora and Sphaerotilus natans using $16 \mathrm{~S}$ rDNA sequence data. Syst Appl Microbiol 16, 219-223.

De Ley, J., Cattoir, H. \& Reynaerts, A. (1970). The quantitative measurement of DNA hybridization from renaturation rates. Eur J Biochem 12, 133-142.

Dondero, N. C. (1961). Sphaerotilus, its nature and economic significance. Adv Appl Microbiol 3, 77-107.

Eikelboom, D. H. (1975). Filamentous organisms observed in activated sludge. Water Res 9, 365-388.

Felsenstein, J. (1993). PHYLIP (phylogeny inference package), version 3.5c. Distributed by the author. Department of Genome Sciences, University of Washington, Seattle, USA.

Fox, G. E., Wisotzkey, J. D. \& Jurtshuk, P., Jr (1992). How close is close: $16 \mathrm{~S}$ rRNA sequence identity may not be sufficient to guarantee species identity. Int J Syst Bacteriol 42, 166-170.

Gerhardt, P., Murray, R. G. E., Costilow, R. N., Nester, E. W., Wood, W. A., Krieg, N. R. \& Phillips, G. B. (editors) (1981). Manual of Methods for General Bacteriology. Washington, DC: American Society for Microbiology.

Gridneva, E. V., Grabovich, M. lu., Dubinina, G. A., Chernousova E. lu. \& Akimov, V. N. (2009). [Ecophysiology of lithotrophic sulfuroxidizing Sphaerotilus species from sulfide springs in the Northern Caucasus]. Mikrobiologiia 78, 89-97 (in Russian).

Guindon, S. \& Gascuel, O. (2003). A simple, fast, and accurate algorithm to estimate large phylogenies by maximum likelihood. Syst Biol 52, 696-704.

Hill, J. E., Town, J. R. \& Hemmingsen, S. M. (2006). Improved template representation in cpn60 polymerase chain reaction (PCR) product libraries generated from complex templates by application of a specific mixture of PCR primers. Environ Microbiol 8, 741-746.
Jukes, T. H. \& Cantor, C. R. (1969). Evolution of protein molecules. In Mammalian Protein Metabolism, vol. 3, pp. 21-132. Edited by H. N. Munro. New York: Academic Press.

Kämpfer, P. (1997). Detection and cultivation of filamentous bacteria from activated sludge. FEMS Microbiol Ecol 23, 169-181.

Kämpfer, P. (1998). Some chemotaxonomic and physiological properties of the genus Sphaerotilus. Syst Appl Microbiol 21, 245-250.

Kämpfer, P. \& Spring, S. (2005). Genus Incertas Sedis XVI. Sphaerotilus Kützing 1833. In Bergey's Manual of Systematic Bacteriology, 2nd edn, pp. 750-755. Edited by D. Y. Brenner, N. R. Krieg \& G. M. Garrity. New York: Springer.

Kützing, F. T. (1833). [Beitrag zur Kenntnis über die Entstehung und Metamorphose der niederen vegetalischen Organismen, nebst einer systematischen Zusammensetzung der hierher gehörigen niederen Algenformen]. Linnaea 8, 335-387 (in German).

Kwok, A. Y., Su, S. C., Reynolds, R. P., Bay, S. J., Av-Gay, Y., Dovichi, N. J. \& Chow, A. W. (1999). Species identification and phylogenetic relationships based on partial HSP60 gene sequences within the genus Staphylococcus. Int J Syst Bacteriol 49, 1181-1192.

Lane, D. J. (1991). 16S/23S rRNA sequencing. In Nucleic Acid Techniques in Bacterial Systematics, pp. 115-175. Edited by E. Stackebrandt \& M. Goodfellow. Chichester: Wiley.

Ludwig, W., Strunk, O., Klugbauer, S., Klugbauer, N., Weizenegger, M., Neumaier, J., Bachleitner, M. \& Schleifer, K. H. (1998). Bacterial phylogeny based on comparative sequence analysis. Electrophoresis 19, $554-568$.

Medlin, L., Elwood, H. J., Stickel, S. \& Sogin, M. L. (1988). The characterization of enzymatically amplified eukaryotic 16S-like rRNA-coding regions. Gene 71, 491-499.

Owen, R. J. \& Lapage, S. P. (1976). The thermal denaturation of partly purified bacterial deoxyribonucleic acid and its taxonomic applications. J Appl Bacteriol 41, 335-340.

Pellegrin, V., Juretschko, S., Wagner, M. \& Cottenceau, G. (1999). Morphological and biochemical properties of a Sphaerotilus sp. isolated from paper mill slimes. Appl Environ Microbiol 65, 156-162.

Pfennig, N. D. \& Lippert, K. D. (1966). Uber das Vitamin B12-Bedurfnis phototropher Schwefelbakterien. Arch Mikrobiol 55, 245-256.

Saitou, N. \& Nei, M. (1987). The neighbor-joining method: a new method for reconstructing phylogenetic trees. Mol Biol Evol 4, 406-425.

Siering, P. L. \& Ghiorse, W. C. (1996). Phylogeny of the SphaerotilusLeptothrix group inferred from morphological comparisons, genomic fingerprinting, and $16 \mathrm{~S}$ ribosomal DNA sequence analyses. Int J Syst Bacteriol 46, 173-182.

Stead, D. E., Sellwood, J. E., Wilson, J. \& Viney, I. (1992). Evaluation of a commercial microbial identification system based on fatty acid profiles for rapid, accurate identification of plant pathogenic bacteria. J Appl Bacteriol 72, 315-321.

Stokes, J. L. (1954). Studies on the filamentous sheathed iron bacterium Sphaerotilus natans. J Bacteriol 67, 278-291.

Thompson, J. D., Gibson, T. J., Plewniak, F., Jeanmougin, F. \& Higgins, D. G. (1997). The CLUSTAL_X windows interface: flexible strategies for multiple sequence alignment aided by quality analysis tools. Nucleic Acids Res 25, 4876-4882.

Van de Peer, Y. \& De Wachter, R. (1994). TREeCON for Windows: a software package for the construction and drawing of evolutionary trees for the Microsoft Windows environment. Comput Appl Biosci 10, 569-570.

van Veen, W. L., Mulder, E. G. \& Deinema, M. H. (1978). The Sphaerotilus-Leptothrix group of bacteria. Microbiol Rev 42, 329-356.

Wayne, L. G., Brenner, D. J., Colwell, R. R., Grimont, P. A. D., Kandler, O., Krichevsky, M. I., Moore, L. H., Moore, W. E. C., Murray, R. G. E. \& other 
authors (1987). International Committee on Systematic Bacteriology. Report of the ad hoc committee on reconciliation of approaches to bacterial systematics. Int J Syst Bacteriol 37, 463-464.

Yamamoto, S. \& Harayama, S. (1995). PCR amplification and direct sequencing of gyrB genes with universal primers and their application to the detection and taxonomic analysis of Pseudomonas putida strains. Appl Environ Microbiol 61, 1104-1109.

Yamamoto, S. \& Harayama, S. (1998). Phylogenetic relationships of Pseudomonas putida strains deduced from the nucleotide sequences of gyrB, rpoD and 16S rRNA genes. Int J Syst Bacteriol 48, 813-819. 